\title{
Ischemia-reperfusion histopathology alterations of the rabbit intestinal wall with and without exclusion of the collateral mesenteric circulation supply ${ }^{1}$
}

\author{
Alterações histopatológicas da parede intestinal de coelhos na isquemia-reperfusão com e sem \\ exclusão da circulação mesentérica colateral
}

\author{
Otoni Moreira Gomes', Geraldo Brasileiro Filho"I, Luiz Alberto Bomjardim Porto ${ }^{\text {III, }}$ Pedro Henrique de Lima Prata ${ }^{\text {III }}$, Rafael \\ de Mattos Paixão ${ }^{\mathrm{IV}}$ \\ I Full Professor, Department of Surgery, School of Medicine, UFMG; Scientific Director São Francisco de Assis Truth is Jesus Cardiovascular \\ Foundation, Belo Horizonte-MG, Brazil.

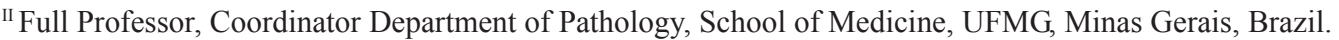

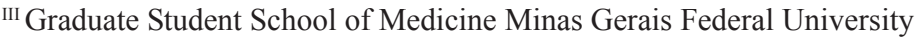 \\ Iv Associate Professor, Coordinator Surgical Technique Division, Surgery Department, School of Medicine, UFMG, Minas Gerais, Brazil.
}

\begin{abstract}
Purpose: To evaluate the histopathology alterations of the intestinal mucosa of rabbits submitted to different times of mesenteric artery ischemia and reperfusion with and without celiac artery collateral circulation supply. Methods: Two groups of eight male New Zealand white rabbits (weight $2.2-3.5 \mathrm{~kg}$ ) were used in this study. In the Group 1 animals, the proximal mesenteric artery was occluded for $60 \mathrm{~min}$ with an atraumatic vascular clamp, followed by reperfusion for $60 \mathrm{~min}$. In the Group 2 animals the small bowel and mesentery were cut $30 \mathrm{~cm}$ and $60 \mathrm{~cm}$ far from the gastroduodenal pyloric transition before the proximal mesenteric artery occlusion. Small bowel biopsies were obtained before ischemia (control), after $30 \mathrm{~min}$ and $60 \mathrm{~min}$ of mesenteric ischemia and at 30 and $60 \mathrm{~min}$. of mesenteric artery reperfusion. Results: In the Group I animals, the followings histopathology grade results were observed: 1 , mean $0.4+0.29$; $\mathrm{t} 2$, mean $1.9 \pm 0.38 ; \mathrm{t} 3,1.9 \pm 0.33 ; \mathrm{t} 4,1.2 \pm 0.36$ and $\mathrm{t} 5,1.2 \pm 0.32$. Differences between $\mathrm{t} 0$ and $\mathrm{t} 2$ and between $\mathrm{t} 3$ and $\mathrm{t} 4 \mathrm{were}$ statistically significant $(\mathrm{p}<0.05)$. Differences between $\mathrm{t} 2$ and $\mathrm{t} 3$ and $\mathrm{t} 4$ and $\mathrm{t} 5$ were not significant $(\mathrm{p}>0.5)$. In the Group II animals, it was observed: $\mathrm{t} 1$, mean $1.6 \pm 0.33 ; \mathrm{t} 2,2.4 \pm 0.36 ; \mathrm{t} 3,3.0 \pm 0.35 ; \mathrm{t} 43.4 \pm 0.31 ; \mathrm{t} 5,3 \pm 031$. Differences between $\mathrm{t} 0$ and $\mathrm{t} 1$, $\mathrm{t} 1$ and $\mathrm{t} 2$, and $\mathrm{t} 2$ and $\mathrm{t} 3 \mathrm{were}$ significant $(\mathrm{p}<0.05)$. Differences between histopathology grades results of samples t 1 to t5 in Group 1 and 2 were statistically significant $(\mathrm{p}<0.5)$. Conclusion: Microscopic examination of the biopsies revealed significant evidence of worse small bowel wall ischemiareperfusion lesions by exclusion of the celiac artery collateral circulation supply.
\end{abstract}

Key words: Mesenteric Vascular Occlusion. Vascular Diseases. Splanchnic Circulation. Rabbits.

\section{RESUMO}

Objetivo: Avaliar as alterações histopatológicas da mucosa intestinal de coelhos submetidos à isquemia-reperfusão com e sem exclusão da circulação mesentérica colateral. Métodos: Foram estudados dois grupos de oito coelhos Nova Zelândia machos com pesos variáveis entre 2,2 e 3,5 $\mathrm{kg}$ de peso corpóreo. Nos animais do Grupo 1, a artéria mesentérica proximal foi ocluida por pinçamento atraumático durante $60 \mathrm{~min}$, seguido de reperfusão por $60 \mathrm{~min}$. No Grupo 2 o intestino delgado e o mesentério foram seccionados $30 \mathrm{~cm}$ e 60 após a transição pilórica gastroduodenal antes da oclusão da artéria mesentérica cranial. Biópsias da parede intestinal foram obtidas antes da isquemia (controle), após 30 e 60 min. de isquemia. Resultados: No Grupo I foram observados os seguintes graus de lesões: t1,média de $0.4+0.29 ; \mathrm{t} 2$, média $1.9 \pm 0.38 ; \mathrm{t} 3,1.9 \pm 0.33 ; \mathrm{t} 4,1.2 \pm 0.36$ e t5, $1.2 \pm 0.32$. As diferenças entre $\mathrm{t} 0$ e $\mathrm{t} 2 \mathrm{e}$ entre $\mathrm{t} 3$ e $\mathrm{t} 4$ foram significantes $(p<0.05)$. As diferenças entre $\mathrm{t} 2$ e $\mathrm{t} 3 \mathrm{e} \mathrm{t} 4 \mathrm{e} \mathrm{t} 5$ não foram significantes $(\mathrm{p}>0.5)$. No Group II observou-se: $\mathrm{t} 1$, média de $1.6 \pm 0.33 ; \mathrm{t} 2,2.4$ $\pm 0.36 ; \mathrm{t} 3,3.0 \pm 0.35 ; \mathrm{t} 43.4 \pm 0.31 ; \mathrm{t} 5,3 \pm 031$. As diferenças entre $\mathrm{t} 0$ e $\mathrm{t} 1$, $\mathrm{t} 1 \mathrm{e} \mathrm{t} 2$, e t 2 e $\mathrm{t} 3$ foram significantes ( $<<0.05$ ). As diferenças entre os resultados histopatológicos das biopsies de t1 a t5 dos Grupos 1 e 2 foram significantes (p<0.5). Conclusão: A exclusão da circulação mesentérica colateral agravou significantemente a degeneração histopatológica na isquemia-reperfusão da parede intestinal. Descritores: Oclusão Vascular Mesentérica. Doenças Vasculares. Circulação Esplâncnica. Coelhos.

${ }^{1}$ Research performed at Laboratory of Experimental Surgery, School of Medicine, Federal University of Minas Gerais (UFMG) and Experimental Research Laboratory São Francisco de Assis Truth is Jesus Cardiovascular Foundation, Belo Horizonte, Brazil.

\section{Introduction}

Parks and Granger ${ }^{1}$ demonstrated by the first time that reperfusion can be more harmful than ischemia separately, opening new frontiers for researches to investigate ischemia and reperfusion physiopathology. Nowadays the ischemia-reperfusion stress is confirmed to affect with different intensity different animal species but with still little reports in the literature regarding 
rabbit intestinal mucosa response. Otherwise, it is known that the anatomical standard of the arterial mesenteric perfusion and correspondent collateral circulation may present very important variations among different animal species but its specific influence in the results of the main, or cranial mesenteric artery, occlusion was not investigated until now.

The objective of this study is to evaluate the histopathology behavior of the intestinal mucosa of rabbits submitted to different times of mesenteric artery ischemia and reperfusion with and without exclusion of celiac trunk branches - mesenteric artery collateral circulation supply.

\section{Methods}

This study was approved by the Ethics Committee for Animal Experimentation of our institutions and was conducted according to the guidelines for animal experimentation of the Brazilian College on Animal experimentation. Two groups of eight male New Zealand white rabbits (weight 2.2-3.5 kg) were used in this study. After an overnight fast with unrestricted access to water, the animals were anesthetized with muscle injections of xilazine $(15 \mathrm{mg} / \mathrm{kg}$ bw) and ketamine $(25 \mathrm{mg} / \mathrm{kg}$ bw) repeated as necessary to maintain an adequate anesthetic plane. Through midline laparotomy, in the Group 1 animals, the proximal mesenteric artery was occluded for 60 min with an atraumatic vascular clamp, followed by reperfusion for $60 \mathrm{~min}$. In the Group 2 animals the small bowel and mesentery were cut $30 \mathrm{~cm}$ and $60 \mathrm{~cm}$ far from the gastroduodenal pyloric transition before the proximal mesenteric artery occlusion. Small bowel biopsies were obtained before ischemia (control), after $30 \mathrm{~min}$ and $60 \mathrm{~min}$ of mesenteric ischemia and at 30 and $60 \mathrm{~min}$. of mesenteric artery reperfusion. Between surgical interventions, the midline incision was sutured to minimize fluid losses. The animals were sacrificed with lethal intravenous dose of anesthetics. The histopathology study was performed in the Pathology Anatomy Laboratory of the Minas Gerais Federal University School of Medicine and results described according to the following classification, modified from Chiu, McArdle, Brown et al. ${ }^{2}$ classification in rats: Grade 0: Normal mucosa histology; Grade 1: Small cytology alterations in the cell structure representation. Increased leucocytes presence and space widening between villosities; Grade 2: Cell alterations with focused lesions and presence of some cell lysis. There are destructions of the the villosities in at most $25 \%$ of their extension; Grade 3: Besides the cytology alterations, there are structural lesions in intermediate extension. Presence of dilated capillaries and higher quantity of inflamed cells. The destruction should be between $25 \%$ and $50 \%$ of the villosities extension; Grade 4: Structural destruction of the villosities, only traces of some villosities, formed by inflamed cells and necrotic material, with hemorrhage and basal glandular ulceration. The destruction should be between $50 \%$ and $75 \%$ of the villosities extension; Grade 5: destruction of all the mucosa, no glandular structure can be seen, only the amorphous material laying on the sub-mucosa tissue. The destruction should be between $75 \%$ and $100 \%$ of the villosities extension (Figure 1). Results are reported as mean \pm standard deviation (SD). The Kruskal-Wallis non parametric method was employed with statistical significance set when $\mathrm{p}<0.5$.

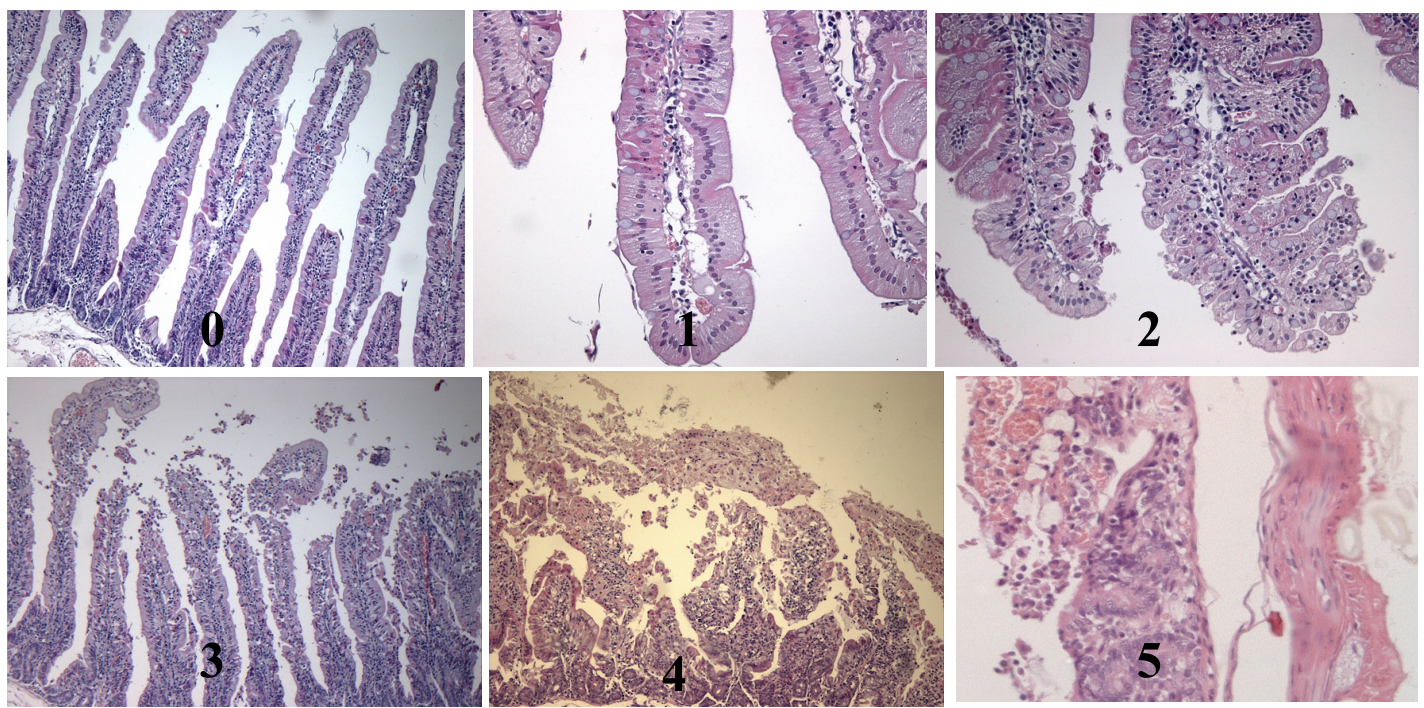

FIGURE 1 - Histopathology lesions intensity (Grade 0 to 5) classification (Modified from Chiu et al. ${ }^{2}$ )

\section{Results}

In the Group I animals, the followings histopathology grade results were observed: $\mathrm{t} 1$, mean $0.4 \pm 0.29$; $\mathrm{t} 2$, mean $1.9 \pm$ $0.38 ; \mathrm{t} 3,1.9 \pm 0.33 ; \mathrm{t} 4,1.2 \pm 0.36$ and $\mathrm{t} 5,1.2 \pm 0.32$ (Table 1 ). Differences between $\mathrm{t} 0$ and $\mathrm{t} 2$ and between $\mathrm{t} 3$ and $\mathrm{t} 4$ were statistically significant $(p<0.05)$. Differences between $\mathrm{t} 2$ and $\mathrm{t} 3$ and $\mathrm{t} 4$ and $\mathrm{t} 5$ were not significant ( $\mathrm{p}>0.5)$. In the Group II animals, it was observed: $\mathrm{t} 1$, mean $1.6 \pm 0.33$; $\mathrm{t} 2,2.4 \pm 0.36$; $\mathrm{t} 3,3.0 \pm 0.35$; t4 $3.4 \pm 0.31$; t5, $3 \pm 031$ (Table 2, Figure 2). Differences between $\mathrm{t} 0$ and $\mathrm{t} 1, \mathrm{t} 1$ and $\mathrm{t} 2$, and $\mathrm{t} 2$ and $\mathrm{t} 3$ were significant $(\mathrm{p}<0.05)$. Differences between histopathology grades results of samples t1 to t5 in Group 1 and 2 were statistically significant $(\mathrm{p}<0.5)$. 
TABLE 1 - Histopathology of Group 1 animals with preserved celiac-mesenteric artery collateral circulation

\begin{tabular}{llllllllll}
\hline \multicolumn{1}{c}{ GROUP $\mathbf{1}-$ HISTOPATHOLOGY CLASSIFICATION } \\
RABBIT
\end{tabular}

TABLE 2 - Histopathology of Group 2 animals with excluded celiac trunk-mesenteric artery collateral circulation

\begin{tabular}{lllllllllll}
\hline \multicolumn{1}{c}{ GROUP 2 - HISTOPATHOLOGY CLASSIFICATION } \\
RABBIT \\
\hline SAMPLES & $\mathbf{1}$ & $\mathbf{2}$ & $\mathbf{3}$ & $\mathbf{4}$ & $\mathbf{5}$ & $\mathbf{6}$ & $\mathbf{7}$ & $\mathbf{8}$ & MEAN & SD \pm \\
to - Control & 0 & 0 & 0 & 0 & 0 & 0 & 0 & 0 & 0 & 0.0 \\
t1 - Ischemia 30' & 3 & 1 & 0 & 1 & 1 & 2 & 3 & 2 & 1.6 & 0.33 \\
t2 - Ischemia 45' & 2 & 1 & 0 & 3 & 3 & 4 & 3 & 3 & 2.4 & 0.36 \\
t3 - Ischemia 60' & 3 & 1 & 1 & 3 & 3 & 4 & 4 & 5 & 3.0 & 0.35 \\
t4 - Reperfusion 30' & 3 & 2 & 2 & 4 & 4 & 4 & 4 & 4 & 3.4 & 0.31 \\
t5 - Reperfusion 60' & 2 & 2 & 2 & 3 & 3 & 4 & 4 & 4 & 3.0 & 0.31 \\
\hline
\end{tabular}

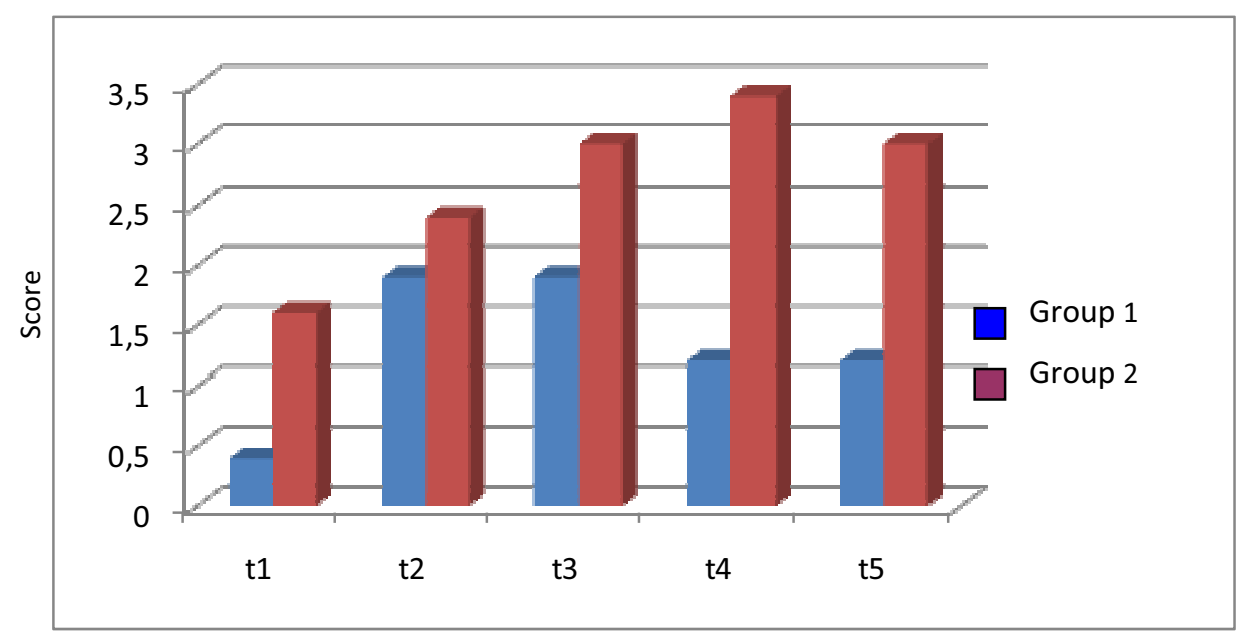

FIGURE 2 - Intestinal tissue lesion variation. Group 1. With celiac-mesenteric collateral circulation. Group 2. Without collateral circulation

\section{Discussion}

The ischemia-reperfusion lesion may complicate many clinical conditions and plays an important role in the pathogenesis and survival following mesenteric blood flow reduction ${ }^{3-5}$, and an extensive research approach have been done ${ }^{6-10}$ to understand the mechanisms of ischemia-reperfusion intestinal injury to obtain the best protection. The occlusion by selective clamping of the cranial mesenteric artery and the one hour ischemic time used being the routine procedure until now in most reported research but not comparatively studied until now the importance of different collateral blood supply due to anatomic variations specie dependents.

The cranial and caudal mesenteric arteries of rabbits are homologous but not proportionally developed like to superior and inferior mesenteric arteries of human beings. The change in nomenclature is due to human bipedalism opposed to cuniculidae quadripedalism. The cranial mesenteric artery of the rabbit sends the middle colic artery, the caudal pancreatic-duodenal artery, and the right colic artery, a branch of ileocolic, and a common trunk, the jejunal arteries ${ }^{11}$. Regarding the caudal mesenteric artery of the rabbit it is a single vessel and very narrow, with source near the 
end of the abdominal aorta, dividing after a short path, at left colic and cranial rectal artery, from which leave the sigmoid arteries ${ }^{12}$. In the present investigation, by macroscopic anatomy and angiography study the caudal mesenteric artery could not be evidenced as important arterial trunk. But the celiac trunk was always present giving the splenic, common hepatic and left gastric artery with branches to the anterior intestine, connected with branches of the cranial mesenteric artery, suggesting that important collateral blood supply could be offered during mesenteric trunk occlusion as usual in the reported mesenteric ischemia-reperfusion studies and it is known that the ischemia-reperfusion stress is confirmed to affect with different intensity different animal species with still little reports in the literature regarding rabbit intestinal mucosa response. The aim of this study was to classify and evaluate the histopathology behavior of the intestinal mucosa of rabbits submitted to different times of mesenteric artery ischemia and reperfusion with and without celiac-mesenteric artery collateral circulation supply to avoid very important bias and results misinterpretation mainly when comparing results from different research centers.

Some inferences may be pointed regarding the possible mesenteric circulatory differences between rabbits and others animals like dogs and pigs and with human anatomy, but it is a matter of fact that in all this mammalian bodies there are circulatory connections between mesenteric artery and celiac trunk branches that are more or less improved time occlusion depending, justifying the possible interference of the collateral circulation and its exclusion in the mesenteric ischemia-reperfusion studies, not mattering the studied animal specie. Otherwise. It would be questioned the advantage of studies focused in the terminal ileum segment to better avoid the celiac trunk collateral perfusion, but this would mask the research objective contribution, because it would be quite far from the clinical use of the research results, as we know that distal bowel lesions are most depending of traumatic small vessel lesions, instead of progressive arteriosclerosis obstruction, without indication for angioplasty neither graft bypass reperfusion, but such procedures are mostly employed regarding mesenteric trunk reperfusions.

The above questions bringing great importance for the complete isolation of possible collateral circulation interferences in mesenteric ischemia-reperfusion studies.

\section{Conclusion}

The obtained results leads to the conclusion that microscopic examination of the biopsies revealed significant evidence of worse small bowel wall ischemia-reperfusion lesions by exclusion of the celiac-mesenteric artery collateral circulation supply.

\section{References}

1. Parks DA, Granger DN. Contributions of ischemia and reperfusion to mucosal lesion formation. Am J Physiol. 1986;250:749-53.

2. Chiu CJ, McArdle AH, Brown R, Scott HJ, Gurd FN. Intestinal mucosal lesion in low-flow states. Arch Surg. 1970;101:478-83.

3. Khanna A, Rossman JE, Fung HL, Caty MG. Intestinal and hemodynamic impairment following mesenteric ischemia/reperfusion. J Surg Res. 2001;99:114-9.

4. Zhou JL, Jin GH, Yi YL, Zhang JL, Huang XL. Role of nitric oxide and peroxynitrite anion in lung injury induced by intestinal ischemia-reperfusion in rats. World J Gastroenterol. 2003;9:1318-26.

5. Arakawa K, Takeyoshi I, Muraoka M, Matsumoto K, MorishitaY. Measuring platelet aggregation to estimate small intestinal ischemiareperfusion injury. J Surg Res. 2004;122:195-202.

6. Mallick H, Yang WX, Winslet MC, Seifalian AM. Ischemia-reperfusion injury of the intestine and protective strategies against injury. Dig Dis Sci. 2004;49;1359-65.

7. Santos CHM, Gomes OM, Pontes JCDV, Miiji LNO, Higa EI. Uso do propofol (2,6 diisopropilfenol) como inibidor da lesão tecidual na isquemia e reperfusão mesentérica. Estudo experimental em ratos. Acta Cir Bras. 2003;18:347-54.

8. Ribeiro ME, Yoshida WB. Reperfusion injury after intestinal ischemia: pathophysiology and experimental models. J Vasc Br. 2005;4(2):183-94.

9. Santos CHM, Gomes OM, Pontes JCDV. Terapêutica medicamentosa na isquemia e reperfusão mesentérica: revisão da literatura. Rev Bras Coloproctol. 2006;26:28-33.

10. Cerqueira NF, Hussni CA, Yoshida WB, Padovani CR. Systemic evaluation on ischemia and reperfusion injury of splanchnic organs in rats. Acta Cir Bras. 2009;24:290-5.

11. Barone R. Artères. In: Barone R (Ed.). Anatomie comparée des mammifères domestiques. Esplancnologie. Paris: Éditions Vigot; 1996. p.327-47.

12. Machado MRF, Souza SV, Oliveira TC, Cortellini LMF, Barbosa RR. Suprimento arterial dos intestinos do coelho da raça Nova Zelândia (Oryctolagus cuniculus). Biotemas. 2007;21:101-5.

\section{Correspondence:}

Otoni Moreira Gomes

Av. Sanitária Dois, 12

31530-000 Belo Horizonte-MG Brazil

Phone/Fax: (55 31)3439-3004

gomes@servcor.com

Conflict of interest: none Financial source: none

\section{How to cite this article}

Gomes OM, Brasileiro Filho G, Porto LAB, Prata PHL, Paixão RM. Ischemia-reperfusion histopathology alterations of the rabbit intestinal wall with and without exclusion of the collateral mesenteric circulation supply. Acta Cir Bras. [serial on the Internet] 2010 July-Aug;25(4). Available from URL: http://www.scielo.br/acb 